\title{
A COOPERAÇÃO JUDICIÁRIA EM MATÉRIA PENAL NA UNIÃO EUROPEIA - A PROVA E $A$ PROTEÇÃO DOS DIREITOS FUNDAMENTAIS
}

\author{
JUDICIAL COOPERATION IN CRIMINAL MATTERS IN THE EUROPEAN UNION - PROOF \\ AND PROTECTION OF FUNDAMENTAL RIGHTS
}

\section{LA COOPERACIÓN JUDICIÁRIA EN MATERIA PENAL EN LA UNIÓN EUROPEA - LA PRUEBA Y LA PROTECCIÓN DE LOS DERECHOS FUNDAMENTALES}

\section{André Paulino Piton ${ }^{1}$}

Licença CC BY: Artigo distribuído sob os termos Creative Commons, permite uso e distribuição irrestrita em qualquer meio desde que o autor credite a fonte original.

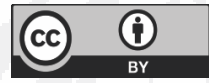

Resumo: AUnião Europeia tem hoje um impressionante conjunto de mecanismos de cooperação judiciária responsáveis pela prevenção e pela repressão da criminalidade no espaço de Liberdade, Segurança e Justiça. A criação destes instrumentos, que permitem a descoberta da verdade material, também levanta alguns problemas sob a ótica da proteção dos direitos dos suspeitos acusados ou de pessoas envolvidas num processo penal com dimensão europeia. Deste modo, não podemos deixar de questionar-nos, de modo prospetivo, sobre qual o caminho a seguir na edificação e na consolidação deste projeto europeu. Para isto, faremos algumas considerações sobre a decisão europeia de investigação em matéria penal e as garantias dos direitos fundamentais como princípios processuais desse espaço que queremos de segurança, mas principalmente de liberdade e justiça.

Palavras-chave: Tratado de Lisboa; Cooperação Judiciaria em matéria Penal; Prova; Processo Penal; Reconhecimento mútuo.

Abstract: The European Union today has an impressive set of judicial cooperation mechanisms for preventing and repressing crime in the area of Freedom, Security and Justice. The creation of such instruments that allow the discovery of material truth also raises some problems when it comes to protecting the rights of suspects, accused persons, or persons involved in criminal proceedings with a European dimension. Thus, we question, in a prospective way, the way forward in building and consolidating this European project. To this end, we offer some considerations about the European decision on criminal investigation and the guarantees of fundamental rights as procedural principles of this space, which is one of security, but mainly of freedom and justice.

Key-words: Treaty of Lisbon; Judicial cooperation in criminal matters; Proof; Criminal proceedings; Mutual recognition.

1 Doutor em Direito. Professor Auxiliar no Instituto Universitário da Maia. Maia, Portugal. Coordenador da Licenciatura em Criminologia do Instituto Universitário da Maia. Maia, Portugal. Diretor Executivo do Laboratório de Ciências Forenses e Criminologia. Investigador integrado do JusGov - Research Centre for Justice and Governance. 
Resumen: La Unión Europea tiene hoy, un impresionante conjunto de mecanismos de cooperación judiciaria responsables por la prevención y por la represión de la criminalidad en el espacio de Libertad, Seguridad y Justicia. La creación de estos instrumentos, que permiten el descubrimiento de la verdad material, también levanta algunos problemas bajo la óptica de la protección de los derechos de los sospechosos acusados o de personas envueltas en un proceso penal con dimensión europea. De este modo, no podemos dejar de preguntarnos, de modo prospectivo, sobre cuál es el camino por seguir en la edificación y en la consolidación de este proyecto europeo. Para esto, haremos algunas consideraciones sobre la decisión europea de investigación en materia penal y las garantías de los derechos fundamentales como principios procesuales de este espacio que se quiere de seguridad, pero principalmente de libertad y justicia.

Palabras-clave: Tratado de Lisboa; Cooperación Judiciaria en materia Penal; Prueba; Proceso Penal; Reconocimiento mutuo.

\section{INTRODUÇÃO}

Sendo a questão da prova o problema central de todo o direito processual ${ }^{2}-\mathrm{e}$ assumindo particular relevo no âmbito das ciências criminais por frequentemente entrar em conflito com direitos fundamentais dos cidadãos envolvidos -, não é de estranhar que os esforços de cooperação policial e judiciária na União Europeia tenham vindo a dirigir-se paulatinamente para esta matéria. Em boa verdade, rapidamente se compreendeu que para lá da detenção e entrega de pessoas para poderem ser alvo dos devidos processos judiciais em país onde não se encontram ${ }^{3}$, a cooperação em matéria penal não poderia fazer-se adequada e eficazmente senão quando se avançasse para a possibilidade de um Estado solicitar a outro que levasse a cabo determinadas diligências investigatórias dentro do seu território,

2 Sobre a questão da prova penal e as especiais dificuldades a qual suscita a sua recolha a nível transnacional, especialmente dentro do espaço da União Europeia, cf., entre a bibliografia abundante, KLIP, André. European Criminal Law. An Integrative Approach, Antwerp: Intersentia, 2009, p. 209 e ss.; ILLUMINATI, Giulio (ed.), Prova Penale e Unione Europea - Atti del Convegno "L'armonizzazione della prova penale nell Unione europea", Bologna: Bononia University Press, 2009; UBERTIS, Giulio. Principi di Procedura Penale Europea - La regole del giustio processo, 2nd edn, Milano: Raffaello Cortine Editore, 2009; JOUTSEN, Matti. 'The European Union and Cooperation in Criminal Matters: the Search for Balance", Heuni Paper, 25, 2006, p. 7-43; DEU, Teresa Armenta; INCHAUSTI, Fernando Gascón. El Derecho Procesal Penal en la Unión Europea, Madrld: Colex, 2006; e, RAMOS, Vânia Costa. "Problemas da obtenção de prova em contexto transnacional - introdução", Revista Portuguesa de Ciência Criminal, 23, 2013, p. 547-568, chamando a atenção para a falta de consenso e análise académica aprofundada do problema. Como bem sublinha a autora, o problema não é apenas de obtenção de prova, mas - e sobretudo - da sua valoração, sendo que a falta de um regime regulatório detalhado e eficiente tem conduzido à implementação de uma "troca de informações com base no princípio da disponibilidade, segundo o qual deve criar-se uma interligação entre os sistemas de informação dos vários Estados, disponibilizando-se o acesso directo por cada Estado-Membro (EM) à informação de todos os outros Estados Membros da UE” (p. 549).

3 O Mandado de Detenção Europeu foi um marco no desenvolvimento da cooperação judicial em matéria penal entre os Estados membros da União Europeia por ser o primeiro instrumento processual penal a ser implementado. O que não quer dizer que até os dias de hoje não se levantem inúmeras dúvidas não apenas sobre a sua eficácia, mas também sobre a sua legitimação à luz do direito interno de cada Estado-Membro. Neste sentido, cf., por todos, RODRIGUES, Anabela Miranda. "O mandado de detenção europeu na via da construção de um sistema penal europeu: um passo ou um salto?", Revista Portuguesa de Ciência Criminal, a. 13, n 1, Janeiro - Março 2003, p. 27-63; GRAÇA, António Pires Henriques da. O Regime Jurídico do Mandado de Detenção Europeu, Coimbra: Coimbra Editora, 2014; VALENTE, Manuel Monteiro Guedes. Do Mandado de Detenção Europeu, Coimbra: Editora Almedina, 2006. 
entregando ao primeiro o respetivo resultado. Só assim se caminharia no sentido de um verdadeiro espaço de liberdade, segurança e justiça ${ }^{4}$, na medida em que quaisquer diligências exigidas para a recolha de provas que venham assegurar a descoberta da verdade material a propósito de um determinado facto poderiam ser levadas a cabo em qualquer um dos países da União Europeia, dependendo da conexão do Estado com o crime em causa e respetivos elementos e não de um específico território (aquele onde o crime tiver ocorrido, por exemplo).

\section{COOPERAÇÃO JUDICIÁRIA EM MATÉRIA PENAL}

Se é certo, todavia, que a compreensão da importância de um mecanismo que viesse permitir tal cooperação se impôs rapidamente, a sua consagração efetiva foi particularmente difícil, pois que os específicos contornos do instrumento a constituir sempre suscitaram acesa discussão, principalmente no que se refere a proteção dos direitos e garantias individuais. Na verdade, ainda que tendo como base o princípio do reconhecimento mútuo, uma tal colaboração entre entidades judiciárias dos diversos países sempre se mostrou particularmente difícil, quer quanto ao tipo de meios de obtenção de prova que pudessem ser utilizados, como quanto à validade dos elementos recolhidos em certo Estado para um processo levado a cabo num outro Estado.

Compreendendo, de há muito ${ }^{5}$, a necessidade de avançarmos para mecanismos particularmente destinadosa lidar com a cooperação investigatória e a recolha de prova, a União Europeia foi adotando alguns instrumentos neste domínio, de que destacamos, desde logo, a decisão-quadro 2003/577/ JAI, do Conselho, de 22 de julho, relativa à execução na União Europeia

$4 \quad$ Os objetivos atribuídos ao espaço de liberdade, segurança e justiça estão enunciados no artigo $67 .^{\circ}$ do Tratado de Funcionamento da União Europeia: "1. A União constitui um espaço de liberdade, segurança e justiça, no respeito dos direitos fundamentais e dos diferentes sistemas e tradições jurídicos dos Estados Membros. 2. A União assegura a ausência de controlos de pessoas nas fronteiras internas e desenvolve uma política comum em matéria de asilo, de imigração e de controlo das fronteiras externas que se baseia na solidariedade entre Estados Membros e que é equitativa em relação aos nacionais de países terceiros. Para efeitos do presente título, os apátridas são equiparados aos nacionais de países terceiros. 3. A União envida esforços para garantir um elevado nível de segurança, através de medidas de prevenção da criminalidade, do racismo e da xenofobia e de combate contra estes fenómenos, através de medidas de coordenação e de cooperação entre autoridades policiais e judiciárias e outras autoridades competentes, bem como através do reconhecimento mútuo das decisões judiciais em matéria penal e, se necessário, através da aproximação das legislações penais. 4. A União facilita o acesso à justiça, nomeadamente através do princípio do reconhecimento mútuo das decisões judiciais e extrajudiciais em matéria civil".

5 Na verdade, desde a Proposta de Corpus luris que este problema foi erigido a um dos núcleos centrais da discussão da União Europeia sobre a matéria penal e processual penal, apesar de ter passado por diferentes fases de evolução. Cf. o que a este propósito nos conta RUGGERI, Stefano. "Introduction to the Proposal of a European Investigation Order: Due Process Concerns and Open Issues"', in Transnational Evidence and Muticultural Inquiries in Europe, Heidelberg: Springer, 2014, p. 4. 


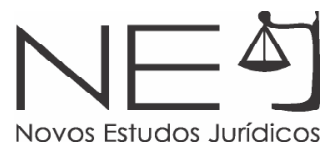

das decisões de congelamento de bens ou de provas ${ }^{6}$. No seguimento das conclusões de Tampere em matéria penal ${ }^{7}$, o Conselho avançou para este primeiro esforço, parcelar, de regulamentação da cooperação judiciária entre os Estados Membros em matéria penal, visando agilizar o modo segundo o qual um país deveria executar uma decisão de congelamento emitida por outro $^{8}$. A tentativa não surtiu, todavia, os efeitos pretendidos, falhando em termos de aplicabilidade e eficiência?

\section{O MANDADO EUROPEU DE OBTENÇÃO DE PROVAS}

No mesmo ano, a Comissão lançou uma proposta para uma decisão-quadro do Conselho sobre um mandado europeu de obtenção de provas para recolha de objetos, documentos e dados, a fim de serem utilizados no âmbito de procedimentos penais ${ }^{10}$. Esta proposta acarretou, contudo, algumas preocupações, sendo muito discutida e criticada, pelo que só cinco anos mais tarde acabaria por ser adotada, dando assim origem à decisão-quadro 2008/978/JAI, do Conselho, de 18 de dezembro, relativa a um mandado europeu de obtenção de provas destinado à obtenção de objetos, documentos e dados para utilização no âmbito de processos penais ${ }^{11}$. Também esta, todavia, como veremos, acabou por não produzir os desejados efeitos.

Na verdade, nos termos no n. 1 do art. 1. ${ }^{\circ}$ daquela decisão quadro, "[o] mandado europeu de obtenção de provas é uma decisão judiciária emitida por uma autoridade competente de um Estado-Membro, tendo em vista a obtenção de objetos, documentos e dados de outro Estado-Membro, para utilização no

$6 \quad$ JO L196, de 2 de agosto de 2003.

7 Estabelecia a conclusão 36: "O princípio do reconhecimento mútuo deverá ainda aplicar-se aos despachos judiciais proferidos antes da realização dos julgamentos, em especial aos que permitam às autoridades competentes recolher rapidamente as provas e apreender os bens que facilmente podem desaparecer; as provas legalmente obtidas pelas autoridades de um Estado-Membro deverão ser admissíveis perante os tribunais dos outros Estados Membros, tendo em conta as normas neles aplicáveis". CONSELHO EUROPEU. Disponível em: http://www. europarl.europa.eu/summits/tam_pt.htm\#b

8 Em Portugal, a decisão em causa foi cumprida através da aprovação da lei n. ${ }^{\circ}$ 25/2009, de 5 de junho (com a declaração de retificação n. ${ }^{\circ} 56 / 99$, de 3 de agosto), que estabelece o regime jurídico da emissão e da execução de decisões de apreensão de bens ou elementos de prova na União Europeia.

9 Cf., a este propósito, RAMOS, Vânia Costa. "Freenzingorder - um nado morto? Primeira abordagem às decisões de congelamento para apreensão de elementos de prova com base na Decisão-Quadro 2003/577/JAl, do Conselho, e na Lei 25/2009, de 05.06", in Cooperação Judiciária Internacional em Matéria Penal. Coimbra: Coimbra Editora, 2014, 287-339.

$10 \mathrm{COM} / 2003 / 0688$ final. Esta proposta pode ser consultada em http://eur-lex.europa.eu/legal-content/PT/TXT/PDF/ ?uri=CELEX:52003PC0688\&from=EN

11 JO L350, de 30 de dezembro de 2008. 
Novos Estudos Jurídicos

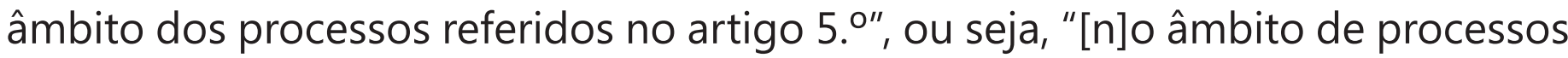
penais instaurados por uma autoridade judiciária ou a instaurar perante uma tal autoridade relativamente a uma infração penal, ao abrigo do direito interno do Estado de emissão"; "[e]m processos instaurados por autoridades administrativas por atos puníveis, ao abrigo do direito interno do Estado de emissão, por configurarem uma violação de normas legais e quando da decisão caiba recurso para um órgão jurisdicional competente, em particular em matéria penal"; "[e]m processos instaurados pelas autoridades judiciárias por atos puníveis, ao abrigo do direito interno do Estado de emissão, por configurarem uma violação de normas legais e quando da decisão caiba recurso para um órgão jurisdicional competente, em particular em matéria penal"; e, por último, "[n]o contexto dos processos referidos nas alíneas a), b) e c) [hipóteses anteriores] relativos a infrações ou violações da lei pelas quais uma pessoa coletiva possa ser considerada responsável ou possa ser punida no Estado de emissão".

No âmbito de um destes processos, portanto, um país poderia solicitar a outro a obtenção, nesse Estado de execução, de objetos, documentos ou dados que entendesse necessários para a prossecução do seu procedimento penal, desde que respeitadas as condições e formalidades previstas na decisão quadro. Mais importante, porém, do que o elenco dos atos permitidos, mostrou-se o conjunto de situações que estão excecionadas, não sendo abrangidas por este mandado de obtenção de provas (decisão-quadro 2008/978/JAI): a condução de interrogatórios, a tomada de declarações ou outros tipos de audições que envolvam suspeitos, testemunhas, peritos ou qualquer outra parte; a realização de exames físicos ou a recolha de elementos materiais ou dados biométricos diretamente de um corpo humano, incluindo amostras de ADN ou impressões digitais; a obtenção de informações em tempo real, designadamente através da interceção de comunicações, de vigilância discreta ou do controlo de contas bancárias; a realização de análises de objetos, documentos ou dados existentes; e a obtenção de dados de comunicações conservados por fornecedores de serviços de comunicações eletrónicas publicamente disponíveis ou por redes públicas de comunicações ${ }^{12}$.

12 Assim estabelecem as diversas alíneas do n..$^{\circ} 2$ do art. $4 .^{\circ}$ da referida decisão quadro. Prevê-se, todavia, no n. ${ }^{\circ} 4$ do mesmo preceito, a possibilidade de tais provas serem requeridas se esses objetos, documentos já se encontrarem na posse da autoridade de execução antes da emissão do mandado. 
A regulamentação deste mandado de obtenção de provas, expressamente assente no princípio do reconhecimento mútuo - tal como resultara das conclusões de Tampere e, depois, fora desenvolvido no Programa de medidas destinadas a aplicar o princípio do reconhecimento mútuo das decisões penais ${ }^{13}$-, enfrentava muitas dificuldades, desde logo espelhadas nos motivos de não reconhecimento ou não execução do mandado (art. $13 .^{\circ}$ da decisão-quadro ${ }^{14}$ ) e na necessidade, ainda que residual, de controlo da dupla incriminação quando esteja em causa a realização de buscas e apreensões ${ }^{15}$ (art. 14. ${ }^{\circ}$ ).

\section{Estando previsto que, até 19 de janeiro de $2011^{16}$, os Estados Membros} tomassem as medidas necessárias à implementação da decisão-quadro em causa, esta acabou por revelar-se um rotundo fracasso, só tendo sido aplicada pela Dinamarca, pela Eslovénia, pela Finlândia e pela Holanda. Todos os outros Estados Membros (incluindo, portanto, Portugal) suscitaram grandes dúvidas a respeito

13 Da conclusão 37 do Conselho Europeu de Tampere resultou a solicitação ao Conselho e à Comissão de que aprovassem, antes de Dezembro de 2000, um programa de medidas destinadas a aplicar o princípio do reconhecimento mútuo em matéria penal, uma vez que o princípio reconhecimento mútuo das decisões judiciais foi considerado a pedra angular da cooperação judiciária na União, tanto em matéria civil como penal. Um tal programa acabaria por ser aprovado pelo Conselho em 29 de novembro de 2000 (2001/C 12/02), JO C12, de 15 de janeiro de 2001.

14 Nos termos do n. ${ }^{\circ} 1$ do art. 13. ․, "[o] reconhecimento ou a execução do mandado europeu de obtenção de provas podem ser recusados pelo Estado de execução se: a) [a] sua execução for contrária ao princípio ne bis in idem; b) [n]os casos referidos no n. ${ }^{\circ} 3$ do artigo $14 .^{\circ}$, o mandado europeu de obtenção de provas respeitar a factos que não constituam infração ao abrigo do direito interno do Estado de execução; c) [n]o caso específico, não for possível executar o mandado europeu de obtenção de provas com as medidas à disposição da autoridade de execução em conformidade com o $\mathrm{n}^{\circ} 3$ do artigo $11 .^{\circ}$; d) [u]ma imunidade ou privilégio concedidos pelo direito interno do Estado de execução tornar impossível executar o mandado europeu de obtenção de provas; e) [n] um dos casos referidos nos $n .{ }^{\circ} \mathrm{s} 4$ ou 5 do artigo $11 .^{\circ}$, o mandado europeu de obtenção de provas não tiver sido validado; f) [o] mandado europeu de obtenção de provas for referente a infrações penais que: i) ao abrigo do direito interno do Estado de execução, sejam consideradas como tendo sido cometidas, no todo, na sua maior parte ou no essencial, no seu território ou em local equivalente, ou ii) foram cometidas fora do território do Estado de emissão, e o direito interno do Estado de execução não permitir que sejam instauradas ações judiciais para esse tipo de infrações quando cometidas fora do território desse Estado; g) [n]o caso específico, a sua execução puder prejudicar interesses nacionais essenciais de segurança, puser em perigo a fonte da informação ou implicar o uso de informação classificada relativa a atividades específicas de informações; ou h) [o] formulário constante do anexo estiver incompleto ou for manifestamente incorreto e não tiver sido devidamente preenchido ou corrigido num prazo razoável pela autoridade de execução".

15 De acordo com o n. 1 do art. $14 .^{\circ}$ da decisão quadro, a regra é a de que o reconhecimento ou a execução do mandado europeu de obtenção de provas não estão subordinados ao controlo da dupla criminalização, salvo se for necessário efetuar uma busca ou apreensão. Mesmo nestes casos, prevê-se, todavia, um conjunto alargado de infrações que, caso sejam puníveis no Estado de emissão com pena ou medida de segurança privativas de liberdade de duração máxima não inferior a três anos, tal como definidas pelo direito interno desse Éstado, não são em caso algum objeto de controlo da dupla criminalização (são, nos termos do n. ${ }^{\circ} 2$ do preceito, hipóteses como as de participação em organização criminosa, terrorismo, tráfico de seres humanos, exploração sexual de crianças e pedopornografia, tráfico ilícito de estupefacientes e substâncias psicotrópicas, tráfico ilícito de armas, munições e explosivos, corrupção, fraude, incluindo a fraude lesiva dos interesses financeiros das Comunidades Europeias, branqueamento dos produtos do crime, falsificação de moeda, incluindo a contrafação do euro, cibercriminalidade, crimes contra o ambiente, incluindo o tráfico de espécies animais ameaçadas e de espécies e variedades vegetais ameaçadas, auxílio à entrada e à permanência irregulares, entre vários outros.

Nos termos do n. ${ }^{\circ} 1$ do art. $23 .^{\circ}$ 
deste mandado europeu de obtenção de provas, não tendo ele ultrapassado os inúmeros obstáculos que lhe foram opostos a nível nacional e que acabaram por impedir a sua transposição nos ordenamentos jurídicos de cada Estado-Membro.

O problema continuou a ser muito debatido e, logo no ano seguinte, reapareceu no Livro Verde sobre a obtenção de provas em matéria penal entre Estados Membros e a garantia de admissibilidade dessas provas ${ }^{17}$, que, fazendo um balanço sobre os instrumentos existentes à data, reconhecia a sua dispersão, fragmentariedade e grandes dificuldades de aplicação, desde logo porque assentes, como sublinhámos já em princípios operativos distintos (o princípio do auxílio judiciário mútuo, por um lado, e o princípio do reconhecimento mútuo, por outro) ${ }^{18}$. Aí se defendia, na senda aliás do que havia já sido feito na Comunicação da Comissão a propósito desta matéria ${ }^{19}$, a substituição do regime jurídico existente sobre a obtenção de provas em matéria penal por um único instrumento, baseado no princípio do reconhecimento mútuo e que abarcasse todos os tipos de provas ${ }^{20}$.

Por outro lado, a aprovação do Tratado de Lisboa modificou substancialmente o quadro normativo dentro do qual se desenvolve a atuação da União Europeia em matéria penal, passando a prever-se no art. 82. ${ }^{\circ}$, n. ${ }^{\circ}$ 2 , al. a) do TFUE a possibilidade de, através de diretivas adotadas de acordo com o processo legislativo ordinário, o Parlamento Europeu e o Conselho estabelecerem regras mínimas respeitantes à admissibilidade mútua dos meios de prova entre os Estados Membros ${ }^{21}$, o que conduziu imediatamente ao

17 COM (2009)624 final. A versão portuguesa pode ser consultada em http://eur-lex. europa.eu/legal-content/PT/ TXT/PDF/?uri=CELEX:52009DC0624\&qid=1433318086120\&from =EM.

18 Como sublinha o Livro Verde, "a regulamentação relativa à obtenção de provas em matéria penal atualmente em vigor na UE compreende vários instrumentos que coexistem entre si e que são baseados em princípios subjacentes distintos, designadamente o princípio do auxílio judiciário mútuo e o princípio do reconhecimento mútuo. Esta situação complica a aplicação das normas e pode causar confusão entre os profissionais, que em alguns casos não utilizam o instrumento mais adaptado às provas pretendidas" (pp. 4-5).

19 Comunicação da Comissão ao Parlamento Europeu e ao Conselho: Um espaço de liberdade, de segurança e de justiça ao serviço dos cidadãos - COM(2009) 262.

20 De acordo com o que se sustentava no referido Livro Verde, "[e]m comparação com o âmbito de aplicação da Decisão-Quadro relativa a um mandado europeu de obtenção de provas, este novo instrumento cobriria igualmente as provas que, embora directamente disponíveis, ainda não existem, como as declarações de suspeitos ou de testemunhas, ou as informações obtidas em tempo real, como a intercepção de comunicações ou a vigilância de contas bancárias. Cobriria igualmente as provas que, embora já existam, não estão directamente disponíveis sem investigação ou exame suplementar, como as análises de dados, de objectos ou de documentos existentes, ou obtenção de material biológico, como amostras de ADN ou de impressões digitais" (p. 5).

21 Esta inovacão do Tratado de Lisboa prevê a possibilidade de criação destas regras mínimas não apenas em matéria de admissibilidade mútua de meios de prova, mas igualmente quanto aos direitos individuais em processo penal, aos direitos das vítimas da criminalidade e a outros elementos específicos do processo penal (desde que identificados previamente pelo Conselho através de uma decisão, que terá de ser deliberada por unanimidade, após aprovação do Parlamento Europeu). 
surgimento de um conjunto de propostas e iniciativas tendentes à substituição dos instrumentos existentes por um único e abrangente mecanismo destinado à recolha de todos os tipos de provas $^{22}$. Ações estas que, aliás, haviam já sido promovidas pelo Programa de Estocolmo ${ }^{23}$, pois que, no respetivo Plano de $A c ̧ a ̃ O^{24}$, a Comissão Europeia anunciou quer a intenção de apresentar uma proposta legislativa tendente à introdução de um regime alargado para a obtenção de provas em direito penal, tendo por base o princípio do reconhecimento mútuo, quer o propósito de propor ações para desenvolver normas mínimas comuns em matéria penal.

\section{A DECISÃO EUROPEIA DE INVESTIGAÇÃO EM MATÉRIA PENAL}

Foi, portanto, neste contexto que, em 2010, um conjunto de Estados Membros $^{25}$ avançou com uma proposta de diretiva relativa à decisão de investigação em matéria penal ${ }^{26}$, tentando antecipar-se à ação da Comissão. A proposta suscitou, uma vez mais, amplas reservas, pelo que a sua negociação, quer dentro do Conselho, quer entre o Conselho e o Parlamento, foi muitíssimo lenta, só se dando por concluída no final de 201327. A diretiva 2014/41/UE, do Parlamento Europeu e do Conselho, acabaria por ser adotada em 3 de abril de $2014^{28}$, fixando um prazo de $3 \operatorname{anos}^{29}$ para a sua transposição para

22 Sublinhando igualmente a importância do quadro legislativo que, entretanto, se fez sentir com a entrada em vigor do Tratado de Lisboa, RUGGERI, Stefano. "Introduction to the Proposal of a European Investigation Order: Due Process Concerns and Open Issues", in Transnational Evidence and Muticultural Inquiries in Europe, Heidelberg: Springer, 2014, p. 5.

23 O Programa de Estocolmo - uma Europa aberta e segura para servir e proteger os cidadãos (2010/C115/01), que foi aprovado em 11 de dezembro de 2009, constitui um roteiro para o trabalho da UE no espaço de justiça, liberdade e segurança para o período entre 2010 e 2014. Este Programa Estratégico (e respetivo Plano de Ação - COM (2010)171 final) para o desenvolvimento do espaço de liberdade, segurança e justiça, traçou seis grandes linhas de atuação: direitos fundamentais e cidadania; justiça civil e penal; segurança interna; fronteiras e vistos; imigração e asilo; e dimensão externa.

24 No que especificamente respeita à justiça penal, aí se sublinhava a importância do princípio do reconhecimento mútuo, especificando que o plano inclui propostas legislativas sobre a obtenção e recolha de provas, sobre decisões de privação de direitos e sobre sanções financeiras em matéria penal. Este Plano de Ação pode ser consultado em http://eur-lex.europa.eu/legal-content/PT/TXT/?uri=uriserv:jl0036.

25 A proposta foi apresentada por sete Estados Membros: Bélgica, Bulgária, Estónia, Espanha, Áustria, Eslovénia e Suécia.

26 A proposta pode ser consultada em http://data.consilium.europa.eu/doc/document/ST-9288-2010-INIT/fr/pdf

27 Para uma visita guiada pelos principais problemas e dificuldades suscitados logo pela proposta de diretiva, cf. RUGGERI, Stefano. "Introduction to the Proposal of a European Investigation Order: Due Process Concerns and Open Issues", in Transnational Evidence and Muticultural Inquiries in Europe, Heidelberg: Springer, 2014, pp. 6 e ss. O autor começa a sua reflexão pelo próprio objeto da proposta de diretiva, questiona a opção por um instrumento legislativo único em matéria de recolha de provas assente numa nova forma de encarar o reconhecimento mútuo e parte, depois, para uma análise acerca de alguns dos seus aspetos mais problemáticos, como sejam as questões de proporcionalidade, meios de obtenção de prova e direitos de defesa.

28 JO L130, de 1 de maio de 2015. Consultar a versão portuguesa em http://eur-lex.europa.eu/legal-content/PT/TXT/ PDF/?uri=CELEX:32014L0041\&from=PT.

29 Na verdade, de acordo com o art. 36. ${ }^{\circ}$ da diretiva, "[o]s Estados Membros tomam as disposições necessárias para dar cumprimento à presente diretiva até 22 de maio de 2017". 
os ordenamento jurídicos internos, pelo que - se os Estados Membros não decidirem colocar entraves à iniciativa - deverá estar em pleno funcionamento no final de maio de $2017^{30}$.

Este instrumento vem, pois, declaradamente, tentar pôr um fim no regime fragmentário até agora vigente nesta matéria, substituindo todas as medidas até agora (co)existentes. Assim, as Convenções de 1959 e de 2000, os Acordos de Schengen e respetiva Convenção de Aplicação (neste âmbito, naturalmente), mas igualmente a decisão de congelamento e o próprio mandado de obtenção de provas, são agora trocados por uma única ferramenta ${ }^{31}$, que simultaneamente procura ter o objeto mais abrangente possível, aplicando-se horizontalmente a quase todas as medidas investigativas ${ }^{32}$. Na verdade, nos termos do art. 3. ${ }^{\circ}$ da diretiva, "[a decisão europeia de investigação] abrange qualquer medida de investigação, com exceção da criação de uma equipa de investigação conjunta e da obtenção de elementos de prova por essa equipa, tal como previsto no artigo 13. ${ }^{\circ}$ da Convenção relativa ao auxílio judiciário mútuo em matéria penal entre os Estados Membros da União Europeia e na Decisão-Quadro 2002/465/JAI do Conselho, exceto para efeitos de aplicação, respetivamente, do artigo $13 .^{\circ}$, n. $^{\circ} 8$, da Convenção, e do artigo $1 .^{\circ}$, n. ${ }^{\circ} 8$, dessa decisão-quadro".

Desta vez, ao contrário do que sucedia com o mandado de obtenção de provas, a decisão de investigação pode ser requerida tanto para obter elementos

30 'Em pleno funcionamento em todos os Estados Membros vinculados à diretiva, que o mesmo é dizer excetuando a Irlanda e a Dinamarca. Ao contrário do Reino Unido, aqueles dois países optaram por fazer funcionar a cláusula opt out e, tal como consta, respetivamente, dos considerandos 44 e 45 da diretiva, não participam na sua adoção da presente diretiva, não ficando a ela vinculados nem sujeitos à sua aplicação.

31 Como afirma, aliás, para que dúvidas não restem, a própria diretiva. Cf. o art. $34 .{ }^{\circ}$, que estabelece: "1. Sem prejuízo da sua aplicação entre Estados Membros e Estados terceiros, e das disposições transitórias previstas no artigo 35. ${ }^{\circ}$, a presente diretiva substitui, a partir de 22 de maio de 2017, as disposições correspondentes das seguintes convenções aplicáveis às relações entre os Estados Membros vinculados à presente diretiva: a) Convenção Europeia de Auxílio Judiciário Mútuo em Matéria Penal, do Conselho da Europa, de 20 de abril de 1959, e os seus dois Protocolos Adicionais, bem como os acordos bilaterais celebrados nos termos do artigo $26 .^{\circ}$ dessa Convenção; b) Convenção de Aplicação do Acordo de Schengen; c) Convenção relativa ao Auxílio Judiciário Mútuo em Matéria Penal entre os Estados Membros da União Europeia, e o respetivo Protocolo. 2. A DecisãoQuadro 2008/978/JAl é substituída para os Estados Membros vinculados pela presente diretiva. As disposições da Decisão-Quadro 2003/577/JAI são substituídas para os Estados Membros vinculados pela presente diretiva, no que respeita ao congelamento de provas. Para os Estados Membros vinculados pela presente diretiva, as referências à Decisão-Quadro 2008/978/JAI e, no que respeita ao congelamento de provas, as referências à Decisão-Quadro 2003/577/JAI devem ser entendidas como referências à presente diretiva".

32 Na verdade, com exceção das equipas de investigação conjuntas e da vigilância transfronteiras, tudo é agora levado a cabo sob a égide da nova decisão europeia de investigação. Nos termos do considerando inicial 8, "[a] decisão europeia de investigação deverá ter um âmbito horizontal, aplicando-se, por conseguinte, a todas as medidas de investigação que visam recolher elementos de prova. Todavia, a criação de equipas de investigação conjuntas e a recolha de elementos de prova por essas equipas requerem regras específicas que é melhor tratar separadamente. Sem prejuízo da aplicação da presente diretiva, os instrumentos existentes deverão portanto continuar a aplicar-se a esse tipo de medidas de investigação". De igual modo, esclarece o ponto seguinte: "[a] presente diretiva não se deverá aplicar à vigilância transfronteiras referida na Convenção de Aplicação do Acordo de Schengen". 
de prova que já estejam na posse das autoridades competentes do Estado de execução, como para que sejam executadas noutro Estado Membro uma ou várias medidas de investigação específicas, tendo em vista a obtenção de elementos de prova (art. 1. ${ }^{\circ}$ ). E tais elementos, na sequência daquela que era já a posição assumida nos instrumentos anteriores neste âmbito, podem dizer respeito tanto (a) a processos penais instaurados por uma autoridade judiciária, ou que possam ser instaurados perante uma tal autoridade, relativamente a uma infração penal ao abrigo do direito interno do Estado de emissão; como (b) a processos instaurados pelas autoridades administrativas em processos referentes a atos puníveis ao abrigo do direito interno do Estado de emissão, por configurarem uma infração à lei, quando caiba recurso da decisão para um tribunal competente, nomeadamente em matéria penal; ou (c) a processos instaurados pelas autoridades judiciárias em processos referentes a atos puníveis ao abrigo do direito interno do Estado de emissão, por configurarem uma infração à lei, quando caiba recurso da decisão para um órgão jurisdicional competente, nomeadamente, em matéria penal; bem como, por último, (d) quando estejam em conexão com processos referidos nas hipóteses anteriores, relativos a crimes ou infrações à lei pelos quais uma pessoa coletiva possa ser responsabilizada ou punida no Estado de emissão ${ }^{33}$.

Além dos preceitos específicos, destinados a regular algumas das mais significativas medidas de investigação (previstas, desde logo, no capítulo IV), como transferência temporária (arts. $22^{\circ}{ }^{\circ}$ e $23 .^{\circ}$ ), a audição por videoconferência (art. 24. ${ }^{\circ}$ ), a audição por conferência telefónica (art. 25. ${ }^{\circ}$ ), a informação sobre contas bancárias e outras operações financeiras (arts. $26 .^{\circ}$ e $27 .^{\circ}$ ), a recolha de elementos de prova em tempo real (art. 28..$^{\circ}$ ), ou as investigações encobertas (art. 29. ${ }^{\circ}$ ), bem como a delimitar os mais graves meios de obtenção de prova (atentese no capítulo $V$, dedicado aos meios de interceção de telecomunicações ${ }^{34}$ ), devemos chamar a atenção para o art. $2 .^{\circ}$ da diretiva, onde, na respetiva al. c), se define o que seja autoridade de emissão da decisão europeia de investigação.

33 Assim preceitua o art. $4 .^{\circ}$ da diretiva. Não podemos deixar de sublinhar alguma estranheza pela técnica legislativa utilizada, nomeadamente quanto à última alínea elencada. Em boa verdade, prevendo as outras três hipóteses a responsabilidade penal, a responsabilidade administrativa (contraordenacional entre nós) e, numa hipótese mais abrangente, a responsabilidade por infração à lei (diremos, civil), não vemos razão para autonomizar os casos relativos à responsabilidade de pessoas coletivas, pois que hão de caber numa dessas hipóteses. A menos que se entenda admissível - como, na verdade, à luz da letra da norma parece ser - que este pedido seja feito em sede de um procedimento que não preveja a possibilidade de recurso para um tribunal. Hipótese que não se nos afigura compaginável com o restante regime previsto para a decisão Europeia de investigação.

Arts. $30 .^{\circ}$ e $31 .^{\circ}$ 
Nos termos do que vai preceituado nesse dispositivo, além de um juiz, de um tribunal, de um juiz de instrução ou magistrado do Ministério Público competente no processo em causa, a decisão de investigação pode ainda ser emitida por "qualquer outra autoridade competente definida pelo Estado de emissão e que, no caso em apreço, atue enquanto autoridade de investigação num processo penal com competência para ordenar a obtenção de elementos de prova no processo de acordo com a lei nacional". Nesta hipótese, todavia, a decisão europeia de investigação terá de ser validada por um juiz, por um tribunal, por um juiz de instrução ou por um magistrado do Ministério Público no Estado de emissão, que verificarão a sua conformidade com a diretiva. Antes de nos debruçarmos sobre um dos aspetos mais problemáticos deste instrumento (o da garantia e proteção dos direitos dos suspeitos e arguidos), queremos ainda chamar a atenção para os motivos de não reconhecimento ou não execução de uma decisão de investigação, previstos no art. $11 .^{\circ}$ da diretiva.

Muito mais limitados do que aqueles que poderiam justificar a recusa nos instrumentos anteriores, falamos aqui da existência de imunidades ou privilégios, ou de regras relativas à liberdade de imprensa e de expressão, da proteção de interesses nacionais essenciais, do princípio ne bis in idem, ou, em alguns casos, da exigência de dupla incriminação 35 . Fora destes casos, a decisão sobre o reconhecimento ou execução deve ser tomada, e a medida de investigação deve ser levada a cabo, com a mesma celeridade e prioridade dos processos nacionais

$35 \mathrm{O}$ n. ${ }^{\circ} 1$ do art. $11 .^{\circ}$ estipula o seguinte: "[s]em prejuízo do artigo $1 .^{\circ}, \mathrm{n} .{ }^{\circ} 4$, o reconhecimento ou a execução de uma decisão europeia de investigação podem ser recusados no Estado de execução se: a) A execução da decisão europeia de investigação é impossível por existir uma imunidade ou um privilégio ao abrigo da lei do Estado de execução que torna impossível a execução da decisão europeia de investigação ou por existirem regras sobre a determinação e limitação da responsabilidade penal no que se refere à liberdade de imprensa e à liberdade de expressão noutros meios de comunicação social que tornam impossível a execução da decisão europeia de investigação; b) Num caso específico, a execução da decisão europeia de investigação for suscetível de prejudicar interesses nacionais essenciais de segurança comprometer a fonte da informação ou implicar o uso de informações classificadas relativas a atividades específicas de informação; c) A decisão europeia de investigação tiver sido emitida no âmbito dos processos referidos no artigo $4 .^{\circ}$, alíneas b) e c), e a medida de investigação não for autorizada pela lei do Estado de execução em processos nacionais semelhantes; d) A execução da decisão europeia de investigação for contrária ao princípio de ne bis in idem; e) A decisão europeia de investigação disser respeito a uma infração penal alegadamente cometida fora do território do Estado de emissão e total ou parcialmente no território do Estado de execução, e a conduta que tiver conduzido à emissão da decisão europeia de investigação não constituir infração no Estado de execução; f) Se houver motivos substanciais para crer que a execução da medida de investigação indicada na decisão europeia de investigação será incompatível com as obrigações do Estado de execução nos termos do artigo $6 .{ }^{\circ}$ do TUE e da Carta; g) A conduta para a qual tiver sido emitida a decisão europeia de investigação não constituir infração à luz da lei do Estado de execução, a menos que se relacione com uma infração incluída nas categorias de infrações constantes do Anexo $D$, conforme indicado pela autoridade de emissão na decisão europeia de investigação, caso seja punível no Estado de emissão com pena ou medida de segurança privativas de liberdade de duração máxima não inferior a três anos; $h$ ) A utilização da medida de investigação indicada na decisão europeia de investigação for limitada pela lei do Estado de execução a uma lista ou categoria de infrações ou a infrações com certo limiar de pena, que não incluam a infração a que a decisão europeia de investigação diz respeito". 


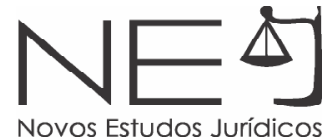

semelhantes e, em todo o caso, dentro dos prazos previstos no art. $12 .^{\circ}$, que prevê um prazo geral para o reconhecimento da Decisão Europeia de Investigação de 30 dias e de 90 para o respetivo cumprimento ${ }^{36}$. Um procedimento, pois, que se ensaia agora muito mais célere, simplificado e simultaneamente abrangente. Tendo por base o princípio do reconhecimento mútuo, uma das suas linhas de força passa a ser, portanto, o papel proeminente da autoridade de emissão e correspondente diminuição de poderes da autoridade do Estado de execução.

\section{OS DIREITOS FUNDAMENTAIS}

Feita esta viagem célere e descritiva pela história da decisão europeia de investigação, bem como pelo seu conteúdo normativo, atenhamo-nos agora um pouco sobre alguns dos seus problemas mais significativos, no que respeita ao equilíbrio entre a necessidade de uma investigação criminal transfronteiriça eficiente e a exigência de adequada proteção dos direitos fundamentais dos cidadãos europeus. Vários aspetos poderiam, a este propósito, ser explorados. Cingir-nos-emos, todavia, a um conjunto deles que, sendo considerados particularmente significativos, foram já suscitados aquando da discussão da proposta de decisão ${ }^{37}$ e não encontraram solução satisfatória na diretiva entretanto aprovada.

36 Prazos esses que, nos termos do art. $12 .^{\circ}$, podem todavia ser distintos: "1. A decisão sobre o reconhecimento ou execução deve ser tomada, e a medida de investigação deve ser levada a cabo, com a mesma celeridade e prioridade dos processos nacionais semelhantes e, em todo o caso, dentro dos prazos previstos no presente artigo. 2. Se a autoridade de emissão tiver declarado na decisão europeia de investigação que, devido aos prazos processuais, à gravidade da infração ou a outras circunstâncias particularmente urgentes, é necessário um prazo mais curto do que o previsto no presente artigo, ou se tiver declarado na decisão europeia de investigação que a medida de investigação tem de ser executada numa determinada data, a autoridade de execução deve ter isso em conta na medida em lhe for possível. 3. A autoridade de execução deve tomar a decisão sobre o reconhecimento ou a execução da decisão europeia de investigação o mais rapidamente possível e, sem prejuízo do disposto no n. ${ }^{\circ} 5$, no prazo de 30 dias após a receção da decisão europeia de investigação pela autoridade de execução competente. 4. A não ser que se verifiquem os motivos de adiamento previstos no artigo $15 .^{\circ}$, ou que os elementos de prova referidos na medida de investigação abrangida pela decisão europeia de investigação já estejam na posse do Estado de execução, a autoridade de execução executa a medida de investigação, sem demora e sem prejuízo do n. ${ }^{\circ} 5$, no prazo de 90 dias a contar da decisão a que se refere o n. ${ }^{\circ}$ 3. 5. Quando, em determinado caso, para a autoridade de execução competente não for viável cumprir o prazo estabelecido no n. ${ }^{\circ} 3$, ou respeitar a data específica estabelecida no n. $^{\circ} 2$, ela informa do facto a autoridade competente do Estado de emissão, sem demora e por qualquer meio, indicando os motivos do atraso e o prazo que considera necessário para a tomada da decisão. Nesse caso, o prazo referido no n. 3 pode ser prorrogado, no máximo, por 30 dias. 6 . Quando, em determinado caso, para a autoridade de execução competente não for viável cumprir o prazo estabelecido no $n .^{\circ} 4$, ela informa do facto a autoridade competente do Estado de emissão, sem demora e por qualquer meio, indicando os motivos do atraso, e consulta a autoridade de emissão sobre o calendário adequado para executar a medida de investigação".

37 Cf., v.g., as considerações tecidas por SPENCER, John R. "The Green Paper on obtaining evidence fron onde Member State to another and securing its admissibility: the Reaction of one British Lawyer", ZIS , 9, 2010, pp. 602-606; LELIERUR, Juliette. "L'application de la reconnaissance mutuelle à l'obtention de preuves pénales dans I'Union européenne: une chance por un droit probatoire français en crise?", ZIS, 9, 2010, pp. 590-601; AMBOS, Kai. "Transnationale Beweiserlangung - 10 Thesen zum Grünbuch der EU-Kommission "Erlangung verwertbarer Beweise in Strafsachen aus einem anderen Mitgliedstaat”, ZIS, 9, 2010, 557-66; BACHMEIER, Lorena. "European Investigation Order for obtaining evidence in the criminal proceedings: study of the Proposal for a European Directive", ZIS, 9, 2010, pp. 580-89; RUGGERI, Stefano. "Introduction to the Proposal of a European Investigation Order: Due Process Concerns and Open Issues", in Transnational Evidence and Muticultural Inquiries in Europe, Heidelberg: Springer, 2014, 3-25. 
Um dos pontos que mais discussão gerou em torno da proposta de decisão europeia de investigação (e, mesmo antes disso, do mandado europeu de obtenção de provas) foi o das garantias individuais dos cidadãos visados pelas medidas investigatórias, sejam eles suspeitos, arguidos ou acusados de um crime. De facto a transnacionalização dos procedimentos de recolha de provas, de troca de informações e, naturalmente, de entrega de pessoas fragilizou muitíssimo a posição dos cidadãos face ao exercício da perseguição penal, pois que à falta de estabelecimento de regras quanto aos seus direitos processuais, somou-se a dificuldade de conhecer e acompanhar o processo (deslocalizado e, frequentemente, até desconhecido) e a ausência de mecanismos jurisdicionais de reação (na maior parte das vezes, a impossibilidade até de saber a que tribunal recorrer).

Este quadro afigurava-se particularmente preocupante quando estava em cima da mesa a adoção de um instrumento europeu de recolha de provas, com aplicação transversal e tendencial automaticidade, potenciando, portanto, o risco para todos os cidadãos europeus. A desigualdade de armas entre a acusação e a defesa aprofundava-se com a (proposta de) adoção de mecanismos claramente pensados em função do interesse da investigação, da perseguição penal, e que não levavam em devida conta a necessidade de equilíbrio com os direito de defesa do arguido. Sublinharam estes aspetos, aliás, diversos organismos e intervenientes no processo de elaboração da diretiva respeitante à decisão europeia de investigação ${ }^{38}$, apontando várias falhas quer à proposta de diretiva, primeiro, quer depois à versão que efetivamente acabou por vingar ${ }^{39}$.

38 Ver, por exemplo, as considerações tecidas pela FAIR TRIALS INTERNATIONAL, "'Fair Trials International's response to the adopted European Investigation Order Directive"', mar. 2014, http://www.fairtrials.org/wp-content/uploads/EIOPosition-Paper1.pdf. Cf., igualmente, SPENCER John R., "The Green Paper on obtaining evidence fron onde Member State to another and securing its admissibility: the Reaction of one British Lawyer", ZIS , 9, 2010, pp. 602-606; e BACHMEIER, Lorena. "'El Exhorto Europeo de Obtención de Pruebas en el Proceso Penal. Estudio y Perspectivas de la Propuesta de Decisíon Marco"', in El Derecho Procesal Penal en la Unión Europea, Madrid: Colex, 2006, pp. 131-178.

39 Na verdade, muitas das falhas apontadas à proposta de diretiva original acabaram por ser consideradas nos seus desenvolvimentos e alterações posteriores, resolvendo alguns dos problemas que lhe eram imputados - ou, pelo menos, tentando apontar caminhos para a sua solução, nem sempre conseguida inteiramente. Nesse grupo estão, por exemplo, as questões relacionadas com a consagração de uma possibilidade de recusa de execução da decisão europeia de investigação quando esteja em causa a salvaguarda de direitos fundamentais, bem como de outros princípios basilares (o que veio a encontrar solução, como referimos já no texto, no art. 11. ${ }^{\circ}$ ), bem como com a inexistência inicial da previsão de que a defesa dos arguidos ou suspeitos pudesse também lançar mão da decisão europeia de investigação, o que violava grosseiramente a igualdade de armas (e foi agora ultrapassado, muito embora apenas em parte, como afirmamos logo no n. ${ }^{\circ} 3$ do art. $1^{\circ}$ ), ou a ausência de regras relativas à proteção de dados pessoais (objeto do art. 20. ${ }^{\circ}$ ), a definição do estatuto da polícia visitante (estabelece claramente o n. 5 do art. $9 .^{\circ}$ que as autoridades de investigação emitentes da decisão europeia de investigação têm, por regra, um papel passivo na execução da mesma), bem como a necessidade de garantir a necessária independểncia à autoridade emitente da decisão europeia de investigação (o art. $\left.2 .^{\circ}, \mathrm{c}\right)$, iii), estatui que a decisão europeia de investigação é validada por um juiz, por um tribunal, por um juiz de instrução ou por um magistrado do Ministério Público no Estado de emissão, após análise da sua conformidade com as condições de emissão). Cf. as considerações que a este respeito são tecidas por BACHMEIER, Lorena. "Transnational Evidence - Towards the Transposition of Directive 2014/41 Regarding the European Investigation Order"', EUCRIM, 2, 2015, pp. 47-59. 


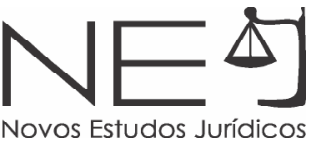

\section{DIREITO DE DEFESA}

Inicialmente, as dúvidas suscitaram-se quanto à (im)possibilidade de utilização do mecanismo europeu de obtenção de provas por parte da defesa, pois que a proposta de diretiva o havia pensado como ferramenta exclusiva da investigação. Assim, a recolha de provas transfronteiriças pela acusação estaria sujeita ao princípio do reconhecimento mútuo, enquanto, por sua vez, a defesa teria de continuar a utilizar os instrumentos próprios da assistência judiciária mútua ${ }^{40}$, 0 que naturalmente cavaria um fosso profundo e desigual entre as duas "partes". Sistematicamente criticada, esta opção da proposta acabaria por ser alterada no texto final, consagrando-se no n. ${ }^{\circ} 3$ do art. $1 .^{\circ}$, como referimos já, a possibilidade de emissão uma decisão europeia de investigação quando requerida por um suspeito ou por um arguido, ou por um advogado em seu nome.

A solução acaba, todavia, por estar consagrada de modo pouco claro e quase só enunciativo, afirmando-se que um tal requerimento há de ser feito "no quadro dos direitos da defesa aplicáveis nos termos do processo penal nacional". Parece, portanto, que caberá aos Estados Membros, na operação de transposição, regular os concretos termos em que este mecanismo funcionará, estabelecendo as regras específicas que efetivarão o exercício deste direito.

Ora, para além de se ver já neste ponto uma hipótese de divergência e disparidade entre os diferentes ordenamentos jurídicos (pois que cada Estado estabelecerá, de acordo com o seu quadro de direitos, aquilo que melhor the aprouver), não nos parece que a consagração desta possibilidade seja suficiente para tornar efetiva a referida - e desejada - igualdade de $\operatorname{armas}^{41}$.

Por um lado, a decisão a respeito da proporcionalidade e necessidade da medida (nos termos do art. 6. ${ }^{\circ}$, n. ${ }^{\circ} 1$ ) cabe à autoridade requerente, mesmo quando o requerimento seja apresentado pela defesa, o que - sobretudo em ordenamentos de moldes mais adversariais - colocará tal poder nas mãos da parte contrária, fragilizando necessariamente a posição do suspeito ou arguido. Além

40 Chamando, igualmente, a atenção para este problema, BACHMEIER, Lorena. "Transnational Evidence - Towards the Transposition of Directive 2014/41 Regarding the European Investigation Order", EUCRIM, 2, 2015, p. 50.

41 No mesmo sentido, crítico quanto à insuficiência de tutela dos direitos da defesa na decisão europeia de investigação, BACHMEIER, Lorena. "Transnational Evidence - Towards the Transposition of Directive 2014/41 Regarding the European Investigation Order”, EUCRIM, 2, 2015, pp. 50-51. 
de que, em qualquer caso, sempre o preenchimento do requerimento implicará que a defesa apresente (à contraparte) a sua estratégia ${ }^{42}$. Por outro, a nível interno, não podemos esquecer que muitas ordens jurídicas não permitem a obtenção autónoma e independente de prova pela defesa, mas apenas que esta apresente à autoridade competente pedidos para a recolha ou produção de determinada prova (como sucede, por exemplo, em Portugal) - o que colocará, obviamente, ainda mais desafios quando a prova em causa seja transnacional. Em última nota quanto a este aspeto, há de anotar-se ainda a falta de qualquer previsão no sentido de a defesa poder participar/assistir à execução da decisão europeia de investigação ${ }^{43}$.

Um outro aspeto, intimamente relacionado com o anterior, que esteve sempre entre os mais vivamente criticados, é o que está relacionado com da falta de disposição legal que preveja a necessidade de notificação dos cidadãos suspeitos ou envolvidos em uma determinada decisão europeia de investigação. Sendo certo, naturalmente, que casos há em que uma tal notificação - prévia não poderá ser feita sob pena de colocar em risco a prova que se pretenda obter, a verdade é que na generalidade dos casos não será assim - como, aliás, não é assim, por exemplo, no nosso direito interno ${ }^{44}$.

De facto, se durante o inquérito o Ministério Público não está obrigado a comunicar ao arguido (ou, menos ainda, ao suspeito) que diligências

42 Nos termos do art. art. $5^{\circ}$ e do formulário constante no anexo A à diretiva, o requerimento de uma decisão europeia de investigação deve conter, pelo menos, os dados relativos à autoridade de emissão e, se aplicável, à autoridade de validação; o seu objeto e justificação; as informações necessárias que estejam disponíveis acerca da pessoa ou pessoas em causa; uma descrição da infração penal que é objeto da investigação ou do processo, e as disposições de direito penal do Estado de emissão aplicáveis; uma descrição da medida ou medidas de investigação solicitadas e das provas a obter.

43 Chamando a atenção para estes e outros problemas, cf. BACHMEIER, Lorena. "Transnational Evidence - Towards the Transposition of Directive 2014/41 Regarding the European Investigation Order", EUCRIM, 2 , 2015 e RUGGERI, Stefano. "Introduction to the Proposal of a European Investigation Order: Due Process Concerns and Open Issues", in Transnational Evidence and Muticultural Inquiries in Europe, Heidelberg: Springer, 2014, p. 17.

44 De facto, a regra no nosso processo penal, de estrutura acusatória integrada por um princípio de investigação, é a da igualdade de armas, que se materializa, desde logo, no direito de o arguido conhecer os factos que lhe são imputados e as provas que contra ele existem, de modo a poder contraditá-las e, assim, exercer um efetivo direito de defesa. Se é certo que, no nosso modelo, o inquérito pode correr sob segredo de justiça (nos termos do art. $86 .^{\circ}$ do CPP), havendo aí algum (ou total) ocultamento das diligências investigatórias que estão a ser levadas a cabo pelo Ministério Público e pelos órgãos de polícia criminal, a verdade é que, desde 2007, tal hipótese é excecional, tendo o legislador afirmado como regra a publicidade de todo o processo, ainda que durante a fase de investigação. Cf., a propósito desta questão e da alteração levada a cabo pela lei n. ${ }^{\circ} 48 / 2007$, de 29 de agosto, por exemplo, PINTO, Frederico de Lacerda da Costa. "'Publicidade e segredo na última revisão do Código de Processo Penal”, Revista do CEJ, 9 (especial), 2008, pp. 7-44; PATTO, Pedro Maria Godinho Vaz. "'O regime do segredo de justiça no Código de Processo Penal revisto”, Revista do CEJ, 9 (especial), 2008, pp. 45-69; e MONTE, Mário Ferreira. "Das consequências processuais em matéria de segredo/publicidade na justiça criminal: irregularidades e nulidades", in Estudos em Homenagem ao Professor Doutor Heinrich Ewald Hörster, Coimbra: Almedina, 2012, p. 1283-1297. 


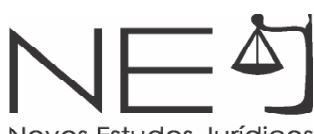

investigatórias está a executar de forma a recolher elementos probatórios que lhe permitam apurar os factos e decidir se deve proferir despacho de acusação ${ }^{45}$ ou de arquivamento, a verdade é que esta liberdade se vê fortemente limitada sempre que os meios de recolha de prova em causa sejam (especialmente) limitadores de direitos, liberdades e garantias do indivíduo em causa. Atente-se, neste sentido, que muito embora o art. $267 .^{\circ}$ do CPP estabeleça, em conformidade com o que vai disposto nos arts. $48 .^{\circ}$ e ss. do mesmo diploma, que o Ministério Público pratica os atos e assegura os meios de prova necessários à realização das finalidades referidas no art. $262 .^{\circ}$, n. $^{\circ} 1$ [a investigação da existência de um crime, a determinação dos seus agentes e respetiva responsabilidade e a descoberta e recolha das provas, em ordem à decisão sobre a acusação], esclarece que este o faz "nos termos e com as restrições constantes dos artigos seguintes".

E nesses preceitos, sobretudo no art. $268^{\circ}{ }^{\circ}$, fixam-se um conjunto de atos que, sendo praticados durante o inquérito, são todavia da competência do juiz de instrução, de modo a garantir a necessária ponderação e proteção dos direitos dos suspeitos e arguidos ${ }^{46}$, ou devem por ele ser expressamente ordenados ou autorizados (nos termos do art. 269. ${ }^{\circ}$ ), com a mesma finalidade ${ }^{47}$.

Se, por outro lado, juntarmos a esta específica exigência de controlo os diversos regimes jurídicos de cada um destes meios de recolha de prova, verificaremos que, na generalidade dos casos, estamos perante atos que são e

45 Ou, porventura, como permite o nosso CPP, tendo recolhido indícios, optar pelo arquivamento em caso de dispensa de pena (art. $280 .^{\circ}$ ) ou pela suspensão provisória do processo (arts. $281 .{ }^{\circ}$ e $282 .^{\circ}$ ).

46 No art. $268 .^{\circ}$ encontramos o elenco dos atos que, durante o inquérito, são da competência exclusiva do juiz de instrução, caracterizando o seu papel de juiz das liberdades: "a) proceder ao primeiro interrogatório judicial de arguido detido; b) proceder à aplicação de uma medida de coação ou de garantia patrimonial, à exceção da prevista no artigo $196 .^{\circ}$, a qual pode ser aplicada pelo Ministério Público; c) proceder a buscas e apreensões em escritório de advogado, consultório médico ou estabelecimento bancário, nos termos do n. ${ }^{\circ} 3$ do artigo $177 . .^{\circ}$, do n..$^{\circ}$ do artigo $180 . .^{\circ}$ e do artigo $181 . .^{\circ} ;$ d) tomar conhecimento, em primeiro lugar, do conteúdo da correspondência apreendida, nos termos do n. 3 do artigo 179. ; e) declarar a perda, a favor do Estado, de bens apreendidos, quando o Ministério Público proceder ao arquivamento do inquérito nos termos dos artigos $277 . .^{\circ}, 280 .^{\circ}$ e $282 . .^{\circ}$; f) praticar quaisquer outros atos que a lei expressamente reservar ao juiz de instrução". Cf. MATA-MOUROS, Maria de Fátima. Juiz das Liberdades: Desconstrução de um Mito do Processo Penal, Coimbra: Almedina, 2011, p. 42 e ss.

47 Nos termos do n..$^{\circ}$ do art. $269 .^{\circ}$ do CPP, "[d]urante o inquérito compete exclusivamente ao juiz de instrução ordenar ou autorizar: a) a efetivação de perícias, nos termos do n..$^{\circ} 3$ do artigo $154 .^{\circ}$; b) a efetivação de exames, nos termos do $n .^{\circ} 2$ do artigo $172 .^{\circ}$; c) buscas domiciliárias, nos termos e com os limites do artigo $177 . .^{\circ}$; d) apreensões de correspondência, nos termos do n. ${ }^{\circ} 1$ do artigo $179 .{ }^{\circ}$; e) interceção, gravação ou registo de conversações ou comunicações, nos termos dos artigos $187 .^{\circ}$ e $189 .^{\circ} ;$ f) a prática de quaisquer outros atos que a lei expressamente fizer depender de ordem ou autorização do juiz". 
têm de ser notificados aos visados ${ }^{48}$, muitas vezes até com acrescidas exigências de comunicação a entidades terceiras (como será o caso, por exemplo, das buscas e apreensões em escritório de advogado, em consultório médico ou em estabelecimento oficial de saúde ${ }^{49}$ ).

Uma tal comunicação tem por objetivo assegurar que a defesa conhece ou pode conhecer que medidas limitadoras de direitos, liberdades e garantias estão a ser levadas a cabo, de modo a que possa sindicar - naquele ou em momento posterior do processo, dependendo dos casos - se uma tal utilização era necessária, adequada e proporcional, cumprindo os pressupostos e finalidades que a lei lhes faz corresponder ${ }^{50}$. Na verdade, tão ou mais importante do que verificar o conteúdo substantivo resultante do meio de obtenção de prova em causa, de modo a poder exercer sobre ele o contraditório, é poder controlar o modo como tais mecanismos são utilizados, aferindo do cumprimento das respetivas formalidades e exigências.

Não se compreende, pois, com facilidade que quando estejamos a falar de um instrumento muito mais intrusivo, utilizado em circunstâncias que respeitam a vários países e que, como sublinhámos já, pela sua própria natureza

48 Vejamos, a título exemplificativo, o que é dito no . $^{\circ} 4$ do art. $154 .^{\circ}$, relativamente às perícias, "[o] despacho é notificado ao Ministério Público, quando este não for o seu autor, ao arguido, ao assistente e às partes civis, com a antecedência mínima de três dias sobre a data indicada para a realização da perícia", e o limites da exceção prevista no seguinte n. ${ }^{\circ} 5$ : "[r]essalvam-se do disposto no número anterior os casos: a) em que a perícia tiver lugar no decurso do inquérito e a autoridade judiciária que a ordenar tiver razões para crer que o conhecimento dela ou dos seus resultados, pelo arguido, pelo assistente ou pelas partes civis, poderia prejudicar as finalidades do inquérito; b) de urgência ou de perigo na demora". Ou, no mesmo sentido, o disposto nos arts. $175 .^{\circ}$ e $176 .{ }^{\circ}$, relativamente às revistas e buscas: "1. Antes de se proceder a revista é entregue ao visado, salvo nos casos do n. ${ }^{\circ} 5$ do artigo anterior, cópia do despacho que a determinou, no qual se faz menção de que aquele pode indicar, para presenciar a diligência, pessoa da sua confiança e que se apresente sem delonga. 2. A revista deve respeitar a dignidade pessoal e, na medida do possível, o pudor do visado" (art. 175. ${ }^{\circ}$ ); "1. Antes de se proceder a busca, é entregue, salvo nos casos do $n .{ }^{\circ} 5$ do artigo $174 .{ }^{\circ}$, a quem tiver a disponibilidade do lugar em que a diligência se realiza, cópia do despacho que a determinou, na qual se faz menção de que pode assistir à diligência e fazer-se acompanhar ou substituir por pessoa da sua confiança e que se apresente sem delonga. 2. Faltando as pessoas referidas no número anterior, a cópia é, sempre que possível, entregue a um parente, a um vizinho, ao porteiro ou a alguém que o substitua. 3. Juntamente com a busca ou durante ela pode proceder-se a revista de pessoas que se encontrem no lugar, se quem ordenar ou efetuar a busca tiver razões para presumir que se verificam os pressupostos do n. ${ }^{\circ} 1$ do artigo $174 .^{\circ}$ Pode igualmente proceder-se como se dispõe no artigo $173 . .^{\circ \prime}$ (art. 176..$^{\circ}$ ).

49 Na verdade, nos termos dos n. ${ }^{\circ} 5$ e 6 do art. 177..$^{\circ}$, "[t]ratando-se de busca em escritório de advogado ou em consultório médico, ela é, sob pena de nulidade, presidida pessoalmente pelo juiz, o qual avisa previamente o presidente do conselho local da Ordem dos Advogados ou da Ordem dos Médicos, para que o mesmo, ou um seu delegado, possa estar presente" e "[t]ratando-se de busca em estabelecimento oficial de saúde, o aviso a que se refere o número anterior é feito ao presidente do conselho diretivo ou de gestão do estabelecimento ou a quem legalmente o substituir".

50 De tal modo que, nos termos da alínea c) do art. $1190^{\circ}$ do Código de Processo Penal português, a ausência do arguido ou do seu defensor, nos casos em que a lei exigir a respetiva comparência gera mesmo nulidade insanável. 
e caraterísticas limita fortemente a capacidade de defesa dos envolvidos, não haja lugar à informação de que a recolha de prova a que se procede está a ser feita ao abrigo de uma decisão europeia de investigação, não podendo a defesa acompanhar e verificar a respetiva obtenção. Ainda que, a posteriori, por exemplo no momento da acusação ou do julgamento, o arguido venha a saber que foram praticadas diligências ao abrigo de uma decisão europeia de investigação, o que Ihe é dado a conhecer é, naturalmente, o produto de uma tal operação, estando coartada a sua efetiva possibilidade de controlar o procedimento.

Esta situação é ainda agravada pelo facto de ter a defesa que lidar com ordenamentos jurídicos diversos, se quiser, v.g., por em causa o modo como foi obtida uma específica prova, não estando usualmente preparada para tal ${ }^{51}$ e tendo que suportar os custos respetivos ${ }^{52}$. Ao que acresce, por último, a específica obrigação de confidencialidade que resulta do art. 19. da diretiva 2014/41/UE, estabelecendo-se que "[c]ada Estado-Membro toma as medidas necessárias para assegurar que na execução da Decisão Europeia de Investigação a autoridade de emissão e a autoridade de execução tenham devidamente em conta a confidencialidade da investigação" ${ }^{\prime 53}$.

51 Na verdade, não é sequer claro qual é o foro em que a defesa deve pôr em causa uma tal obtenção de prova, quando o que pretende impugnar é, por exemplo, a forma como tal prova foi recolhida: no processo que corre no Estado requerente e ao abrigo do qual foi solicitada a decisão europeia de investigação ou, antes, junto dos tribunais do Estado que executou o pedido? Para não falar já, claro, das questões que estão relacionadas não com a produção da prova, mas com a sua valoração. Cf., a propósito, as considerações de BACHMEIER, Lorena. "Transnational Evidence - Towards the Transposition of Directive 2014/41 Regarding the European Investigation Order", EUCRIM, 2, 2015, pp. 55 e ss., e, entre nós, neste caso especificamente sobre a valoração de tais provas, RAMOS, Vânia Costa. "Problemas da obtenção de prova em contexto transnacional - introdução",

Revista Portuguesa de Ciência Criminal, 23 , 2013, pp. 547-68.

52 Vejamos que a diretiva 2013/48/UE, do Parlamento Europeu e do Conselho, de 22 de outubro de 2013 relativa ao direito de acesso a um advogado em processo penal e nos processos de execução de mandados de detenção europeus, e ao direito de informar um terceiro aquando da privação de liberdade e de comunicar, numa situação de privação de liberdade, com terceiros e com as autoridades consulares (JO L294, de 6 de dezembro de 2013), nada prevê a este propósito. O mesmo sucede, aliás, na proposta de diretiva do Parlamento Europeu e do Conselho relativa ao apoio judiciário provisório para suspeitos ou arguidos privados de liberdade e ao apoio judiciário em processos de execução de mandados de detenção europeus - COM (2013) 824 final. PARLAMENTO EUROPEU. Diretivas. Disponível em: https://eur-lex.europa.eu/legal-content/PT/TXT/PDF/?uri=CELEX:32013L0048\&from=EN.

53 Assim dispõe o n. ${ }^{0} 1$ do preceito. Os restantes disciplinam ainda em mais detalhe esta obrigação: "2. A autoridade de execução garante, nos termos da sua lei nacional, a confidencialidade dos factos e do conteúdo da decisão europeia de investigação, exceto na medida do necessário para executar a medida de investigação. Se a autoridade de execução não puder cumprir o requisito de confidencialidade, notifica sem demora a autoridade de emissão. 3. A autoridade de emissão, nos termos da sua lei nacional e salvo indicação em contrário da autoridade de execução, não divulga quaisquer elementos de prova ou informações fornecidos pela autoridade de execução, exceto na medida em que a sua divulgação seja necessária para as investigações ou para o processo descritos na decisão europeia de investigação. 4. Cada Estado-Membro toma as medidas necessárias para assegurar que os bancos não revelem ao cliente em questão ou a terceiros que foram transmitidas informações ao Estado de emissão de acordo com os artigos $26 .^{\circ}$ e $27 .^{\circ}$ ou que está em curso uma investigação". 
Um outro aspeto comumente apontado como um dos mais preocupantes defeitos da decisão europeia de investigação é aquele que está relacionado com a baixa proteção concedida em caso de transferência de pessoas sob custódia. De facto, nos termos dos arts. $22 .^{\circ}$ e $23 .^{\circ}$ da diretiva, de entre os meios que podem ser utilizados para recolha de prova estão as possibilidades de transferência temporária para o Estado de emissão de pessoas detidas para efeito de levar a cabo uma medida de investigação $0^{54}$ e, no sentido oposto, de transferência temporária para o Estado de execução de pessoas detidas para o mesmo efeito ${ }^{55}$.

$\mathrm{Na}$ verdade, muito embora estes preceitos prevejam expressamente o alargamento das hipóteses de não reconhecimento ou de não execução da decisão europeia de investigação nos casos em que a pessoa detida não der o seu consentimento ou a transferência for suscetível de prolongar a detenção da pessoa detida ${ }^{56}$, estes motivos surgem como mera possibilidade, não estando o Estado obrigado a recusar o respetivo pedido. O que redundará - ou poderá redundar, se preferirmos - numa transferência de pessoa detida feita contra a sua vontade expressa. O que é tão mais grave quanto, na diretiva, nada é dito acerca das condições de custódia no país para que o cidadão tenha de ser transferido.

Deve ainda sublinhar-se - num outro eixo de análise que não aprofundaremos aqui, mas que está igualmente relacionado com a proteção de direitos fundamentais dos cidadãos europeus, embora numa diferente perspetiva - as fragilidades da diretiva relativa à decisão europeia de investigação no que respeita à proteção dos direitos de terceiros que possam ser afetados aquando da execução de uma decisão. De facto, além de algumas normas relativas ao depoimento de testemunhas e peritos através de videoconferência, telefone ou outros meios de transmissão audiovisual ${ }^{57}$, nada se estabelece quanto à defesa de terceiros que possam, por

54 Nos termos no n. ${ }^{\circ} 1$ do art. $22 .^{\circ}$, "[p]ode ser emitida uma decisão europeia de investigação para a transferência temporária de uma pessoa detida no Estado de execução, tendo em vista levar a cabo uma medida de investigação para recolha de provas em que seja necessária a sua presença no território do Estado de emissão, desde que a pessoa seja enviada de volta para o Estado de execução no prazo por este estabelecido".

$55 \mathrm{O}$ n. ${ }^{\circ} 1$ do art. $23 .^{\circ}$, por sua vez, estabelece o seguinte: "[p]ode ser emitida uma decisão europeia de investigação para a transferência temporária de uma pessoa detida no Estado de emissão, tendo em vista levar a cabo uma medida de investigação para recolha de provas em que seja necessária a sua presença no território do Estado de execução".

56 De acordo com o preceituado no.$^{\circ} 2$ do artigo $22 .^{\circ} \mathrm{e}$, por remissão, no n. ${ }^{\circ} 2$ do art. $23 .{ }^{\circ}$ (muito embora, neste último, caso apenas para a primeira hipótese - falta de consentimento da pessoa detida).

57 Estatuídas nos art. $24 .^{\circ}$ e $25 .^{\circ}$ da diretiva. 
qualquer razão, ver-se atingidos pela investigação. Seria importante, pois, assegurar que tais pessoas são informadas das medidas em causa, garantindo-se-Ihes forma adequada de protegerem os seus direitos ${ }^{58}$, uma vez que, de outra forma, podem ser envolvidas num processo penal num outro país, verem os seus direitos, liberdades e garantias atacados, e não terem sequer a consciência de que tal sucede.

\section{CONSIDERAÇÕES FINAIS}

Assim, e considerando estas breves ponderações sobre alguns dos pontos que julgamos ser as que mais cabalmente evidenciam determinadas debilidades na efetivação da decisão europeia de investigação em matéria penal - mas que de modo algum esgotam todas as suspeições que sobre ela incidem, sobretudo quanto à sua adequação às garantias individuais decorrente do chamado Estado de democrático de direito -, não colocamos em causa a necessidade da criação de uma estrutura célere de recolha de prova entre os Estados Membros da União Europeia, de modo a facilitar a responsabilização individual e coletiva de ações criminais transnacionais. Entendemos, porém, que qualquer movimento neste sentido, liderado pela União Europeia, deva ser, ele próprio, um dos principais elementos no procedimento de promoção do respeito e manutenção dos direitos e garantias individuais. Os instrumentos da União Europeia devem ser utlizados como impulsionadores, ao mais alto nível, dos direitos, liberdades e garantias e não como meios de nivelamento por baixo dos sistemas interestatuais, assegurando apenas um standard mínimo dessas garantias, como, na realidade, se tem vindo a verificar.

Não há dúvidas de que a implementação e o desenvolvimento do espaço de liberdade, segurança e justiça favorecem o crescimento de uma criminalidade que deixa de ter nas fronteiras territoriais dos Estados os limites das suas ações e, deste modo, contam com um determinado grau de impunidade, pois que os Estados, isolados na aplicação dos seus próprios meios de justiça, permanecem limitados pelos princípios territoriais que servem de base à aplicação do seu sistema penal, incapazes de prevenir ou reprimir esta criminalidade. Faz todo o

58 Acompanhamos, portanto, uma vez mais, as reflexões pertinentes de BACHMEIER, Lorena. "Transnational Evidence - Towards the Transposition of Directive 2014/41 Regarding the European Investigation Order", EUCRIM, 2,2015 , p. 50. No entendimento da autora, caberá agora às leis nacionais, na transposição da presente diretiva, estabelecer regras que venham ao encontro desta necessidade, garantindo os direitos de terceiros envolvidos. Da nossa parte, temos dúvidas que, sem uma palavra a este propósito por parte do legislador europeu, vá agora o legislador nacional atentar no problema e encontrar-lhe solução adequada. 
sentido, nessa medida, que também os Estados devam sobrepor-se às limitações territoriais para poderem ser apuradas responsabilidades, fazendo aplicar a justiça e fortalecendo, assim, o tão almejado espaço de liberdade, segurança e justiça.

No entanto, temos que ponderar que instrumentos, como o que motivou o presente trabalho, podem cobrar-nos uma parcela injustificada da nossa liberdade em prol da formação de um sistema que demonstra ser cada vez mais securitário, e cuja eficácia é dúbia, resultando numa inversão de princípios que, além de contrária ao espírito da União Europeia, tornar-se-á perigosa. Que sentido fará, afinal, a construção de um sistema que tem por fundamento garantir a liberdade se é este mesmo sistema o maior agressor daquela a quem deveria defender?

\section{REFERÊNCIAS DAS FONTES CITADAS}

AMBOS, Kai. "Transnationale Beweiserlangung - 10 Thesen zum Grünbuch der EU-Kommission "Erlangung verwertbarer Beweise in Strafsachen aus einem anderen Mitgliedstaat", ZS, 9, 2010.

BACHMEER, Lorena. "El Exhorto Europeo de Obtención de Pruebas en el Proceso Penal. Estudio y Perspectivas de la Propuesta de Decisíon Marco", in El Derecho Procesal Penal en la Unión Europea, Madrid: Colex, 2006.

BACHMEIER, Lorena. "European Investigation Order for obtaining evidence in the criminal proceedings: study of the Proposal for a European Directive", ZS, 9, 2010.

BACHMEIER, Lorena. "Transnational Evidence - Towards the Transposition of Directive 2014/41 Regarding the European Investigation Order", EUCRIM, 2 , 2015.

CONSELHO EUROPEU. Disponível em: http://www.europarleuropa.eu/summits/tam_pt.htm\#b

DEU, Teresa Armenta; INCHAUSTI, Fernando Gascón. El Derecho Procesal Penal en la Unión Europea, Madrid: Colex, 2006.

FAIR TRIALS INTERNATONAL, "'Fair Trials International's response to the adopted European Investigation Order Directive", mar. 2014, http://www.fairtrials.org/wp-content/uploads/EIO-Position-Paper1.pdf.

GRAÇA, António Pires Henriques da. O Regime Jurídico do Mandado de Detenção Europeu, Coimbra: Coimbra Editora, 2014.

ILLUMINATI, Giulio (ed.), Prova Penale e Unione Europea - Atti del Convegno "L'armonizzazione della prova penale nell' Unione europea", Bologna: Bononia University Press, 2009.

JOUTSEN, Matti. "The European Union and Cooperation in Criminal Matters: the Search for Balance", Heuni Paper, 25, 2006, p. 7-43. 
KLP, André. European Criminal Law. An Integrative Approach, Antwerp: Intersentia, 2009.

LELERUR, Juliette. "L'application de la reconnaissance mutuelle à l'obtention de preuves pénales dans I'Union européenne: une chance por un droit probatoire français en crise?", ZS, 9, 2010.

MATA-MOUROS, Maria de Fátima. Juiz das Liberdades: Desconstrução de um Mito do Processo Penal, Coimbra: Almedina, 2011.

MONTE, Mário Ferreira. "Das consequências processuais em matéria de segredo/publicidade na justiça criminal: irregularidades e nulidades", in Estudos em Homenagem ao Professor Doutor Heinrich Ewald Hörster, Coimbra: Almedina, 2012.

PARLAMENTO EUROPEU. Diretivas. Disponível em: https://eur-lex.europa.eu/legal-content/PT/TXT/PDF/? uri=CELEX:32013L0048\&from $=E N$.

PATTO, Pedro Maria Godinho Vaz. "O regime do segredo de justiça no Código de Processo Penal revisto", Revista do CEJ, 9 (especial), 2008.

PINTO, Frederico de Lacerda da Costa. "Publicidade e segredo na última revisão do Código de Processo Penal", Revista do CEJ, 9 (especial), 2008.

RAMOS, Vânia Costa. "Freenzingorder - um nado morto? Primeira abordagemàs decisões decongelamento para apreensão de elementos de prova com base na Decisão-Quadro 2003/577/JAI, do Conselho, e na Lei 25/2009, de 05.06", in Cooperação Judiciária Internacional em Matéria Penal. Coimbra: Coimbra Editora, 2014.

RAMOS, Vânia Costa. "Problemas da obtenção de prova em contexto transnacional - introdução", Revista Portuguesa de Ciência Criminal, 23, 2013.

RODRIGUES, Anabela Miranda. "O mandado de detenção europeu na via da construção de um sistema penal europeu: um passo ou um salto?", Revista Portuguesa de Ciência Criminal, a. 13, n 1, Janeiro Março 2003.

RUGGERI, Stefano. "Introduction to the Proposal of a European Investigation Order: Due Process Concerns and Open Issues", in Transnational Evidence and Muticultural Inquiries in Europe, Heidelberg: Springer, 2014.

SPENCER John R., "The Green Paper on obtaining evidence fron onde Member State to another and securing its admissibility: the Reaction of one British Lawyer", ZS , 9, 2010.

UBERTIS, Giulio. Principi di Procedura Penale Europea - La regole del giustio processo, 2nd edn, Milano: Raffaello Cortine Editore, 2009.

VALENTE, Manuel Monteiro Guedes. Do Mandado de Detenção Europeu, Coimbra: Editora Almedina, 2006.

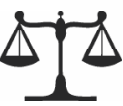

